JURNAL RESPIRASI

$J R$

Vol. 1 No. 2 Mei 2015

\title{
Pneumonitis Akut dan Gagal Napas Setelah Mendapatkan Injeksi Silikon Cair di Payudara
}

Cut Diana Laili, Daniel Maranatha

Departemen Pulmonologi dan IImu Kedokteran Respirasi, Fakultas Kedokteran Universitas Airlangga/RSUD Dr Soetomo

\begin{abstract}
Background; Liquid silicone is a synthetic polymer incorporating oxygen and the semimetallic element silicon. It is widely used in plastic and reconstructive surgery as it displays little change in physical characteristicswith temperature and age, is poorly immunogenic, and is not carcinogenic. Case; We report a case of a 27-year-old woman presented to the hospital with the chief complain progressive shortness of breath, pleuritic chest pain, productive cough, hemoptysis and fever after liquid silicone injections to the mammae for cosmetic augmentation. Physical examination: tachycardia, tachypneu, hypertermia and diffuse rhonchi throughout the lungs. Abnormalities laboratory tests gave leuchositosis, granulositosis, increasing trassaminase serum, D-dimer elevation, Arterial blood gas analysis results respiratory disstres tipe 1. Chest radiograph showed difus bilateral infiltrates, CT angiography was negative for an acute embolus but demonstrated infiltrates in superior lobus dextra, segment lateral lobus medius dan segment apicoposterior Sinistra. Conclusion; Patients with diagnosis of acut pneumonitis and respiratory disstres syndroma after liquid silicone injection to the mammae, supportive therapy with $\mathrm{O} 2$ Ventilator and methylprednisolon low dose gives satisfactory result with radiological and clinical
\end{abstract}

Key words: Silicone, Pneumonitis, Silicone Pneumonitis

\section{PENDAHULUAN}

Silikon adalah polimer cair yang umum digunakan dalam prosedur kosmetik terutama untuk koreksi cacat kontur. Silikon (polydimethylsiloxane) cair bersifat tahan lama, mengalami sedikit perubahan sifat fisik dengan penuaan, dan tidak memiliki imunogenisitas. Hal ini mengarah ke aplikasi luas dalam bedah plastik dan rekonstruksi. Silikon ini tidak sepenuhnya aman dan dalam uji klinis telah diamati adanya komplikasi lokal (misalnya infeksi, nekrosis, dan reaksi benda asing) dan komplikasi sistemik (misalnya, limfadenopati dan penyakit demam akut). Di Amerika Serikat, silikon digunakan oleh dokter untuk operasi kosmetik. Namun injeksi yang dilakukan oleh orang awam/ non medis juga telah dilaporkan. Suntikan sejumlah besar silikon dapat mengakibatkan migrasi dari silikon, granulomatous hepatitis, reaksi paru yang berat, dan bahkan kematian. ${ }^{1-4}$

Injeksi silikon subkutan dapat menimbulkan disfungsi paru akut seperti, emboli paru, pneumonitis akut, perdarahan paru akut, kerusakan alveolar difus, pneumonitis granulomatosa akut dan limfadenitis serta akhirnya dapat menyebabkan kematian. Setelah beberapa hari setelah injeksi, sebagian kasus akan berkembang menjadi gagal napas akut. 5

Dalam laporan kasus ini akan diuraikan seorang penderita dengan pneumonitis akut, gagal napas tanpa emboli paru setelah injeksi silikon cair pada payudara.

\section{KASUS}

Seorang perempuan, Ny SS, berusia 27 tahun, ibu rumah tangga dengan 2 putra,berdomisili di jalan Diponegoro Kanwa 7 KM 14-A. Masuk rumah sakit (MRS) dengan keluhan sesak napas. Penderita MRS di ROI dan rawat bersama dengan Bagian Paru.

Sesak napas dirasakan mendadak sejak 6 jam sebelum masuk rumah sakit (SMRS), semakin memberat, tidak dipengaruhi oleh aktivitas dan tidak hilang dengan istirahat. 3 hari SMRS penderita mendapatkan injeksi silikon cair di payudara kiri dan kanan oleh pegawai salon (non medis) di sebuah salon, setelah itu merasakan nyeri dada dan napas terasa berat. Penderita juga mengeluhkan batuk darah dan 
demam sejak 3 hari SMRS. Tidak mempunyai riwayat batuk lama, nafsu makan menurun, maupun penurunan berat badan. Penderita mengeluhkan diare sejak 5 hari yang lalu, dan buang air kecil dalam batas normal. Penderita berobat ke praktek dokter umum namun tidak merasa ada perbaikan. Penderita mempunyai riwayat merokok 1 bungkus perhari, pemakaian narkoba dan minuman keras.

Berdasarkan pemeriksaan fisik dengan keadaan umum penderita lemah dengan penurunan kesadaran, GCS 345. Tensi 129/74 mmHg, nadi 136x/menit, frekuensi napas32x/ menit, suhu $38^{\circ}$ C. Dari kepala leher tidak didapatkan anemis, ikterik, sianosis, namun terlihat sesak napas berat. Tidak ada pembesaran kelenjar getah bening dan tidak ada peningkatan tekanan vena jugularis.

Berdasarkan pemeriksaan jantung: ictus cordis di ICS V linea midclavicula sinistra, suara jantung (S1 dan S2) tunggal, tidak didapatkan ekstra sistol, gallop maupun murmur. Pada pemeriksaan paru: Inspeksi didapatkan bentuk dan pergerakan toraks simetris dan didapatkan beberapa titik hematom di daerah payudara kiri dan kanan. Palpasi didapatkan fremitus raba hemitoraks kiri dan kanan simetris. Perkusi didapatkan suara sonor di hemitoraks kiri dan kanan, auskultasi suara napas vesikuler pada hemitorak kiri dan kanan. Didapatkan suara ronki di kedua lapangan paru namun tidak didapat suara wheezing.

Berdasarkan pemeriksaan abdomen: perut tampak rata, tidak terdapat kolateral. Hepar dan lien tidak teraba dan bising usus dalam batas normal. Pada pemeriksaan ekstremitas tidak terdapat jari tabuh, akral hangat dan tidak terdapat edema di keempat ekstremitas. Berdasarkan Pemeriksaan darah didapatkan; Hb 10.3 gr/dl, leukosit $13.400 / \mathrm{mm} 3$, granulosit $84,3 \%$, trombosit $235.000 / \mathrm{mm} 3$, APTT 24.9/26.6, PTT 13.1/12.3, glukosa $128 \mathrm{mg} / \mathrm{dl}$, BUN $10.8 \mathrm{mg} / \mathrm{dl}$, kreatinin $0.42 \mathrm{mg} / \mathrm{dl}$, AST $71 \mathrm{IU} / \mathrm{L}$, ALT $73 \mathrm{IU} /$ L,albumin $3.6 \mathrm{~g} / \mathrm{dl}$, HBS Ag, Na 144mmol/l, K 4.7mmol/ I,Cl $107 \mathrm{mmol} / \mathrm{l}$, HIV Rapid test negatif. Berdasarkan Pemeriksaan BGA didapatkan pH 7.40, PCO2 $33 \mathrm{mmHg}$, PO2 $56 \mathrm{mmHg}, \mathrm{HCO} 320.4 \mathrm{mmol} / \mathrm{l}, \mathrm{BE}:-4.4 \mathrm{mmol} / \mathrm{SO} 2$ 89\%, AaDO2 52 mmHg. PF: 70 dan pemeriksaan D-dimer didapatkan D-dimer $1.40 \mathrm{ug} / \mathrm{ml}$

Berdasarkan foto toraks AP/ later didapatkan Cor: besar dan bentuk kesan normal, pulmo: tampak perselubungan dengan air bronkogram di kedua lapang paru. Sinus prenikokostalis kanan kiri anterior posterior tajam. Retrosternal dan retrocardial space tertutup perselubungan. Tampak gambaran udara pada soft tissue mammae kanan kiri. Dengan kesimpulan yaitu Keradangan paru dapat merupakan proses spesifik curiga emphysema subcutis regio mammae kanan kiri. Penderita didiagnosa sementara yaitu; sesak napas, gagal napas dan opasitas homogen, ass: pneumonitis akut dan emboli paru.

Saat MRS Penderita juga melakukan pemeriksaan penunjang lainnya seperti;

1. Pemeriksaan EKG didapatkan Irama sinus takikardi 140x/menit, axis normal

2. Pemeriksaan Echocardiografi; a. Poor Echo window

- Katup-katup tidak tampak kelainan

- Dimensi Ruang jantung; LA Normal (LA mayor $3.3 \mathrm{~cm}$; LA minor $2.6 \mathrm{~cm}$ ), LV normal (LVIOd $4.9 \mathrm{~cm}$ ), RA normal (RA mayor $3.0 \mathrm{~cm}$; RA minor 2,7), RV normal (RUDB $2.6 \mathrm{~cm}$ ), Tidak tampak trombus/vegetasi intrakardiak

- Fungsi sistolik LV normal (EF by teich 59\%), Fungsi diastolik LV E/A fusion, Fungsi sistolik RV normal (TAPSE $1,8 \mathrm{~cm}$ )

- Analisa segmental LV normokinetik

- Tidak terdapat LVH (LVDMI $94.28 \mathrm{~g} / \mathrm{m}^{2} ; \mathrm{RWT}$ $0.35 \mathrm{G}$ )

b. Hemodinamik

- PCWP: 13.06 mmHg, SVR: 1098 dynes.sec/ $\mathrm{cm}^{5}$, PVR: 300.23 dynes.sec/ $\mathrm{cm}^{5}$, CO: $5.10 \mathrm{~V}$ min, Cl: $3.23 \mathrm{l} / \mathrm{min} / \mathrm{m}^{2}$, PHT ringan: PVAccT $104 \mathrm{~ms}$

3. Konsul kardiologi didapatkan penderita dengan kecurigaan emboli paru yang belum dapat disingkirkan

4. Konsul BTKV didapatkan pasien dengan Silikon mammae dextra et sinistra + susp. emboli paru. Saran: Bidang TKV belum ada tindakan khusus. Bila pasien telah sadar dan stabil akan direncanakan CT-Scan thorax + kontras

5. Pemeriksaan seperti Smear sputum BTA, Smear sputum gram, Smear darah gram, kultur sputum aerob, Kultur darah aerob didapatkan hasil negatif

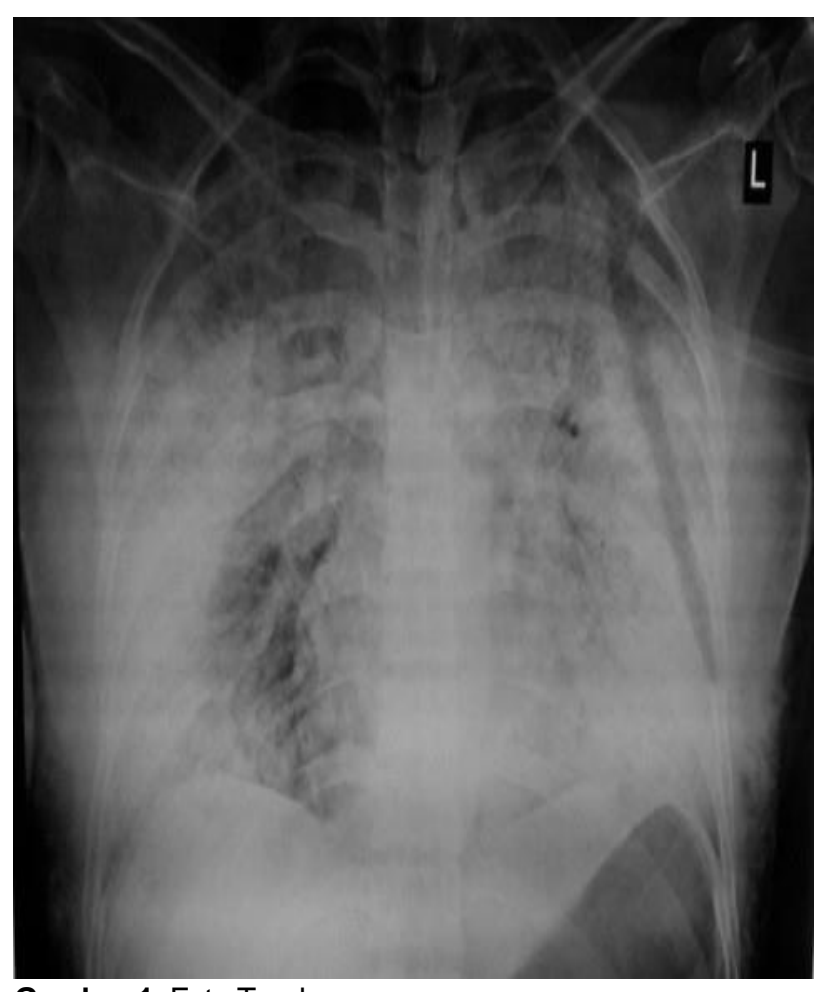

Gambar 1. Foto Toraks. 


\section{PERKEMBANGAN PENDERITA}

Perkembangan dan perjalanan penyakit pada penderita dibagi menjadi 2 periodedalam 2 Minggu perawatan:

1. Saat MRS di RSUD Dr. Soetomo Surabaya dan dirawat di Ruang Observasi Intensif 1: Selama periode ini secara subjektif keadaan umum penderita cukup. GCS pasien adalah 4x6. Pada pemeriksaan tanda vital didapatkan tekanan darah $110 / 70 \mathrm{mmHg}$, nadi $80 \mathrm{x} /$ menit, frekuensi pernapasan $20 \times /$ menit, dan suhu $36,5^{\circ}$ C.

Pada pemeriksaan fisik paru didapatkan: inspeksi dan palpasi simetris, perkusi sonor di kedua lapang paru, auskultasi ronki di 2/3 atas kedua lapang paru. Diagnosis yang dibuat pada periode ini adalah gagal napas + pneumonitis akut dd emboli paru. Rencana diagnosis adalah CT Scan. Terapi yang diberikan O2 ventilator, posisi slight head up, suction kalau perlu, IVFD RL $1500 \mathrm{cc} / 24$ jam, spinal midazolam 2-4 mg/ jam, ranitidin $2 \times 50 \mathrm{mg}$ iv, ceftriaxon $2 \times 1 \mathrm{gr}$ iv, drip

levofloxacin $1 \times 750 \mathrm{mg}$, injeksi metil prednisolon 3 $\times$

$62.5 \mathrm{mg}$ iv.

2. Perawatan di ruang Palem II: Selama periode ini secara subjektif keadaan umum penderita cukup. Tidak didapatkan sesak napas, tetapi masih didapatkan batuk. GCS pasien adalah 456. Pada pemeriksaan tanda vital didapatkan tekanan darah 110/80 $\mathrm{mmHg}$, nadi $84 \mathrm{x} /$ menit, frekuensi pernapasan $22 \times /$ menit, dan suhu $36,6^{\circ}$ C. Pada pemeriksaan fisik paru didapatkan: inspeksi dan palpasi simetris, perkusi sonor di kedua lapangan paru, auskultasi sudah tidak didapatkan ronki seperti periode sebelumnya
Diagnosis yang dibuat pada periode ini berdasarkan data tambahan adalah Pneumonitis akut akibat injeksi silikon cair di payudara. Terapi yang diberikan infus Nacl 0,9\% 14 tetes permenit, diet TKTP $2100 \mathrm{kkal}$ perhari, ambroxol 3x1 tab, omeprazol $2 \times 1 \mathrm{iv}$, metil prednisolon $1 \times 62,5 \mathrm{mg}$ iv, chest fisioterapi, mobilisasi duduk-berdiri-jalan bertahap.

Berdasarkan perkembangan penderita selama enam belas hari secara subjektif didapatkan keadaan umum penderita semakin membaik, tidak didapatkan sesak napas maupun batuk. Pada pemeriksaan tanda vital didapatkan tekanan darah 120/80 mmHg, nadi $84 x /$ menit, frekuensi pernapasan $20 \times /$ menit, dan suhu $36,8^{\circ} \mathrm{C}$. Pada pemeriksaan fisik paru tidak didapatkan kelainan. Penderita dipulangkan dengan terapi pulang metil Prednisolon $3 \times 4 \mathrm{mg}$, ambroxol $3 \times 1$ tab, dan omeprazol $2 \times 1$ tab. Penderita diminta untuk kontrol ke Poli Paru kembali

\section{PEMBAHASAN}

Silikon cair merupakan polimer sintetis menggabungkan oksigen dan elemen silikon semimetalik. Hal ini banyak digunakan dalam bedah plastik rekonstruksi untuk menampilkan sedikit perubahan karakteristik fisik dan usia, sifat imunogenik silikon buruk, namun tidak karsinogenik. Penggunaan dalam keperluan medis yang sah, silikon harus diasingkan dari jaringan lunak. Jika bahan yang mengandung silikon terkena kejaringan lunak, maka akan menghasilkan respons fibroblastik yang secara bertahap akan meningkatkan volume lokal. Oleh karena itu injeksi silikon menggoda beberapa pasien yang mendambakan

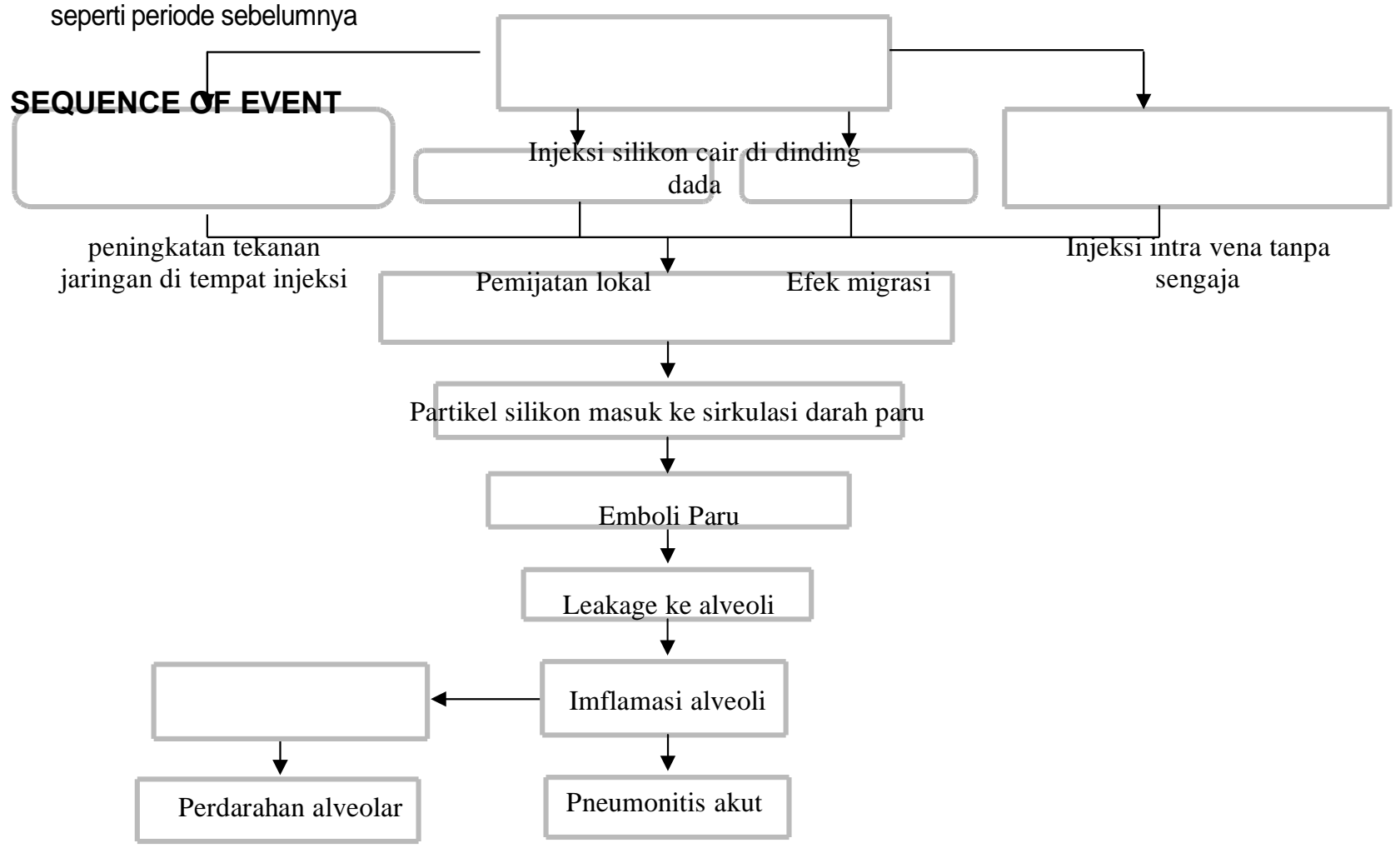


bokong atau payudara yang besar meskipun yang menawarkan bukan praktisi yang mempunyai ijin yang sah. ${ }^{3}$ Pada kasus ini penderita seorang perempuan berusia 27 tahun, seorang ibu rumah tangga yang menginginkan payudaranya membesar agar terlihat lebih cantik.

Injeksi silikon dapat menimbulkan penyulit di paru yang disebut sebagai Severe Pulmonary toxicity, yaitu pneumonitis akut, sindrom gangguan pernapasan akut, dan emboli paru. ${ }^{1,3,6,7}$ Ada dua bentuk pneumonitis setelah injeksi silikon subkutan, yaitu bentuk akut yang terjadi segera atau beberapa hari setelah mendapatkan injeksi ditandai dengan sesak napas mendadak, demam, nyeri dada dan kadang - kadang disertai hemoptisis. Bentuk akut pneumonitis dapat disertai hipoksemia sedang - berat dan gagal napas akut ${ }^{1-4}$. Sedangkan delayed reactivity baru muncul dalam beberapa bulan sampai lebih dari 1 tahun setelah mendapatkan injeksi silikon terakhir. ${ }^{1,3,4}$

Pasien ini sudah merasakan nyeri dada, batuk darah dan demam setelah mendapatkan suntikan silikon cair di payudara kanan dan kirinya 3 hari sebelum merasakan sesak napas mendadak sehingga datang ke IRD dr. Soetomo. Gejala - gejala tersebut menunjukkan pasien mengalami pneumonitis akut.

Mekanisme toksisitas belum jelas, namun ada empatteori yang disebutkan pada kasus injeksi silikon ilegal, yaitu: injeksi intra vena yang tidak disengaja, peningkatan tekanan jaringan di tempat injeksi, pijatan lokal oleh praktisi ilegal, dan efekmigrasi. ${ }^{1,3,6}$ Pada kasus ini injeksi subkutan silikon dilakukan di sebuah salon biasa yang tidak memiliki tenaga ahli maupun ijin untuk melakukan praktek injeksi silikon sehingga injeksi intravena yang tidak disengaja merupakan hal yang mungkin dialami oleh pasien ini.

Meskipun mekanisme toksisitas belum jelas, ada teori yang menyatakan bahwa partikel kecil silikon secara bertahap menyebar ke dalam sistem peredaran darah. Kemudian mengendap diarteriol kecil sehingga meningkatkan tekanan arteri pulmonalis yang menyebabkan cor pulmonale. Partikel silikon masuk ke ruang alveolar sehingga terjadinya embolisasi di paru. Lalu timbul proses imflamasi yang melibatkan sel - sel mediator lokal limfosit, makrofag dan neutrophil yang akan menghancurkan partikel silikon hingga menyebabkan pneumonitis akut, disertai alveolar hemorrhage dengan edema alveolar. ${ }^{1-4,8}$

Chastre dkk menunjukkan bahwa substansi diperoleh dari cairan bronchoalveolar lavage pada beberapa pasien mereka, persis sama sebagai silikon cair yang telah disuntikkan. Dengan kata lain, silikon telah memperoleh akses ke sistem darah vena dalam keadaan tidak berubah dan telah terjadi embolisasi ke paru. ${ }^{6}$ Temuan patologis termasuk perdarahan alveolar, endapan silikon dalam alveoli dan inklusi makrofag alveolar pada biopsi paru mengungkapkan adanya infiltrasi silikon ke dalam ruang alveolar. Respons ini mirip dengan pola cedera yang terlihat pada pneumonia lipoid eksogen, patologi tradisional akibat menghirup zat berminyak (lemak cair).,
Gambaran radiologi pada foto toraks menunjukkan infiltrat merata yang bilateral dan gambaran patchy. Dari Computed tomography (CT- Scan ) pada kasus pneumonitis akut akibat cedera silikon biasanya menunjukkan polaground-glass opacities di daerah perifer, dan atenuasi yang rendah di lapang paru yang terkena dampak, hal ini menyerupai sindrom gangguan pernapasan akut dan Pneumonia. ${ }^{13,9,10}$

Terapi yang diberikan dapat konservatif, tirah baring, terapi oksigenasi sampai penggunaan ventilator pada beberapa kasus. Penderita ini datang dengan sesak napas hebat, RR 32x/menit yang tidak respons dengan oksigenasi, akhirnya diberikan bantuan respirator. Penderita berangsurangsur membaik dengan pemberian kortikosteroid, metil prednisolon $3 \times 62,5 \mathrm{mg}$ tanpa meninggalkan sequele, namun pada penelitian Chen dkk, melaporkan ada kasus yang dijumpai sequele berupa fibrosis paru. ${ }^{1-4,6}$

Belum ada konsensus mengenai penggunaan terapi kortikosteroid pada kasus seperti ini. Tapi pada pasien ini pemberian kortikosteroid dini menunjukkan perbaikan yang signifikan. Laporan kepustakaan menyebutkan belum ada kegunaan yang jelas akan pemberian steroid. ${ }^{1-4}$ Zamora dkk, melaporkan lima kasus silikon terkait pneumonitis semua pulih dengan pengobatan steroid, tetapi mengakui bahwa respons steroid tidak dapat dibuktikan karena tidak ada pasien yang tidak mendapatkan kortikosteroid sehingga tidak dapat dibandingkan. Terapi steroid sering digunakan pada gagal napas akut yang tidak jelas penyebabnya. ${ }^{3,7}$

Manifestasi klinis yang dominan pada toksisitas silikon akibat terhirup atau injeksi subkutan adalah hipoksemia, dyspnea, batuk, demam, nyeri dada, batuk darah, dan penurunan kesadaran. ${ }^{1-4}$ Pada emboli paru akibat injeksi silikon cair juga memberi gambaran klinis sesak napas, batuk, batuk darah dan demam, sehingga emboli paru harus dimasukkan sebagai salah satu diagnosis banding. Pasien ini datang dengan keluhan sesak napas mendadak, nyeri dada, batuk dan batuk darah 3 hari setelah injeksi silikon cair di kedua payudaranya.

Dari beberapa penelitian menyebutkan emboli silikon cair terlibat sebagai penyebab dari pneumonitis akut dengan perdarahan alveolar terutama pada pasien menjalani injeksi silikon untuk pembesaran jaringan. ${ }^{1-3}$ Pada pasien dengan emboli silikon ditemukan hipoksemia (92\%), dyspnea $(88 \%)$, demam $(70 \%)$, dan alveolar hemorrhage $(64 \%)$. Schmid dkk, mencatat kesamaan antara presentasi klinis pasien dengan emboli lemak dan emboli silikon, serta menyimpulkan bahwa patogenesis keduanya serupa. Namun manifestasi dari kejadian emboli akut akibat silikon melibatkan gejala neurologis, termasuk gangguan kesadaran dan koma, dan cepat fatal.,11 Pada penderita ini dilakukan CT- Angiografi untuk memastikan ada tidaknya emboli paru dengan hasil keradangan paru di lobus superior kanan, segment lateral lobus medius dan segment apicoposterior kiri tanpa gambaran emboli paru.

Pemeriksaan Bronchoscopy untuk mendapatkan spesimen bronchoalveolar lavage (BAL) dan Transbronchial 
Biopsy Alveolar (TBA) dapat membantu untuk penegakan diagnosa pneumonitis akut dd emboli paru.Pengecatan cairan BAL yang menemukan mikro dan makrovakuolar yang inklusi kedalam makrophag alveolar menunjukkan adanya silikon. Peningkatan jumlah makrofag alveolar, neutrofil dan eosinofil, serta adanya inklusi globular dalam makrofag adalah karakteristik dan menegaskan diagnosis pneumonitis setelahinjeksi silikon. Pada pasien ini tidak dilakukan BAL dan TBA. ${ }^{1-4}$

\section{KESIMPULAN}

Telah dilaporkan seorang perempuan, 27 tahun, datang ke RSUD dr. Soetomo dengan keluhan sesak napas medadak, nyeri dada, batuk, batuk darah dan demam setelah mendapatkan injeksi silikon cair di kedua payudara. Pemeriksaan fisik: takikardi, takipneu, hipertermi dan ronki di kedua lapang paru. Didapatkan abnormalitas laboratorium leukositosis, granulositosis dan peningkatan serum transaminase, D-Dimer meningkat $(1.40 \mathrm{ug} / \mathrm{ml})$, BGA: gagal napas tipe 1, echokardiografi hemodinamik menunjukkan PCWP: $13.06 \mathrm{mmHg}$ dan gambaran foto toraks infiltrat difus bilateral.Pada pemeriksaan CTAngiografi Keradangan paru di lobus superior kanan, segment lateral lobus medius dan segment apicoposterior kiri dan tak tampak gambaran emboli paru. Keadaan pasien setelah mendapatkan perawatan dan pengobatan tampak perbaikan.

\section{DAFTAR PUSTAKA}

1. Parikh R, Karim K, Parikh N, et al. Case report and literature review: acute pneumonitis and alveolar hemorrhage after subcutaneous injection of liquid silicone. Ann Clin Lab Sci. 2008; 38 (4): 380-385.

2. Clark RF, Cantrell FL, Pacal A, et al. Subcutaneous silicone injection leading to multi-system organ failure. Clin Toxicol (Phila). 2008; 46 (9): 834-837.

3. Essenmacher CA, Astani SA. Respiratory disease following Illicitinjection of Silicone: Case Rep Med. 2013

4. Pastor E, Andreu AL, and Chiner E. Acute pneumonitis and adultrespiratory distress syndromeafter subcutaneous injection of liquid silicone. Arch Bronconeumol. 2005; 41 (12): 702-3

5. Hariri LP, Gaissert HA, Brown R. Progressive granulomatous pneumonitis in response to cosmetic subcutaneous silicone injections in a PatientWith HIV-1 Infection, Case Report and Review of the Literature. Arch Pathol Lab Med. 2012; 136: 204-207

6. Kim CH, Chung DH, Yoo G et al. A case of acute pneumonitis induced by injection of silicone for colpoplasty. Respiration 2003; 70 (1): 104-106.

7. Zamora AC, Collard HR, Barrera L, et al. Silicone injection causing acute pneumonitis: Lung 2009; 187 (4): 241-244

8. Yataco CA,Mendoza JD,Stone. Exogenous lipoid pneumonia following subcutaneous injection of liquid silicone: Report of a Case and Review of the Literature.Chest2011;140

9. Sateesh PG, Sharma S,Surujpal $S$, et al. Acute pneumonitis secondary to subcutaneous silicone injection.Int J Gen Med. 2011; 4: 477-479.

10. Gurvits GE. Silicone pneumonitis after a cosmetic augmentation procedure. N Engl J Med. 2006; 354 (2): 211-212.

11. Schmid A, Tzur A, Leshko L, Krieger BP. Silicone embolismsyndrome: a case report, review of the literature, and comparisonwith fat embolism syndrome. Chest 2005; 127: 2276-81. 